\title{
Prevalence and determinants of hypertension among business class community of Lahore, Pakistan
}

\author{
*Muhammad Asim Farooq ${ }^{1}$, Saima Rehmat ${ }^{1}$, Ammara Ijaz Rana ${ }^{4}$, Maryam Farooqui ${ }^{2}$, Muhammad Soban ${ }^{1}$, Rai Waqas Ali ${ }^{1}$, \\ Adil Saleem ${ }^{1}$, Usama Jamshaid ${ }^{3}$, Rabail Kanwal ${ }^{3}$, Kalim Ullah ${ }^{1}$, Irfan Bashir ${ }^{3,4}$ \\ ${ }^{1}$ Faculty of Pharmacy, Lahore College of Pharmaceutical Sciences, Lahore, Pakistan \\ ${ }^{2}$ Faculty of Pharmacy, University Technology, Mara Malaysia \\ ${ }^{3}$ Faculty of Pharmacy, University of Central Punjab, Lahore, Pakistan \\ ${ }^{4}$ Foundation for Young Researchers, Lahore, Pakistan
}

\begin{abstract}
Hypertension is one of the leading health issue in developing countries. There are many factors associated with hypertension like obesity, excessive intake of salt, smoking and drinking alcohol. Current study aims to assess the prevalence and determinants of hypertension among business class community in Lahore. A community based survey in Lahore was conducted to evaluate the prevalence and determinants in business class community aged 20- 45 year. Questionnaire was designed, translated into local language and 400 participants were interviewed as per structured questionnaire, collected data was analyzed using statistical software SPSS 22. The prevalence of hypertension among study population was $37.5 \%$. Results were astonishing only $32 \%$ of hypertensive patients were taking antihypertensive pills. Being overweight was strongly associated with hypertension, also excessive salt intake and sedentary life style were the contributing factors. There is dire need of awareness to be related hypertension among business class community counselling them about salt intake, smoking and regular exercise.
\end{abstract}

Key Words: Smoking, Obesity, Cholesterol, Stress, Stroke, Socioeconomic status.

\section{INTRODUCTION}

Hypertension is considered to be a major issue in many developing countries. It is also as called silent killer which is correlated with other diseases like organ damage and other non-communicable diseases. The occurrence of hypertension is very high in world one billon individuals are suffering from hypertension and death ratio is also found to be very high i.e. approximately 7.1 million per year (Ogah and Rayner, 2013).

According to the world health organization statistics (2012), one billion adult people had a hypertension and it will be increased in upcoming years to 1.56 billion till 2050 (Keshari and Shankar, 2015). Hypertension is mainly associated with many social life issues. Excessive intake of salt, stress, physiological factors and alcohol consumption are the leading causes of hypertension (Ibrahim and Damasceno, 2012).

The occurrence of hypertension is associated with other risk factors and diseases like congestive heart failure $(\mathrm{CHF})$, end stage renal failure (ESRD), stroke and coronary artery disease (Gupta et al., 2016). According to the JNC 7 guidelines, hypertension is defined as when systolic blood pressure $\geq 140 \mathrm{mmHg}$ or diastolic blood pressure $\geq 90$ mmHg (Premkumar et al., 2016). The recent studies have shown that South Asians population i.e. Pakistan, India, Bangladesh, Nepal and Sri Lanka contribute the highest ratio of the cardiovascular diseases compared to other countries. Previous studies have shown that the prevalence of hypertension reported from Pakistan is $26 \%$ which differ by $34 \%$ among males and $24 \%$ in females (Ke et al., 2015).

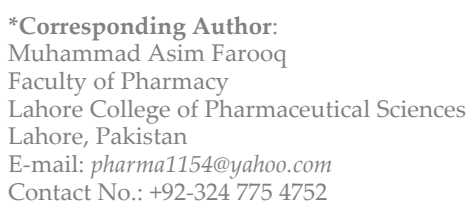

\section{METHODOLOGY}

The present study was conducted to observe the prevalence of hypertension among business class community at Hafeeze Center, Pace Shopping Mall \& Zainab Tower Lahore, Pakistan. Both males and females were included in study population. Ethical approval was obtained from participants of study. The data was obtained from participants, based upon structured questionnaire. The questionnaire was developed in English, translated into local language i.e. Urdu. The questionnaire was comprised of demographic data, dietary habits, family history, socioeconomic status and smoking habits.

Blood pressure was measured with help of sphygmomanometer and BMI was calculated of all the study participants. Study population included both males and females having age between 20-45 years. Results were analyzed with the help of SPSS-22.

\section{RESULTS AND DISCUSSION}

Results of survey conducted on 400 businessmen \& women working in Hafeeze Center, Pace Shopping Mall and Zainab Tower are represented in tables 1-7.

$37.5 \%$ of surveyed individuals were hypertensive. It was shown in this survey that among all the investigated factors affecting B.P. and leading to hypertension; weight, BMI and stress were most important. As compared to males more of the females were under study stress and some of those who continually remained depressed and anxious had B.P. values falling under hypertension. Out of 400 business class persons, 97 males and females had BMI (a function of weight and height) $>24.5$ and $31 \%$ of these 97 people had B.P. values categorized under hypertension. Those having BMI values in normal range (18.4-24.5) were found to have B.P. values within normal range as well. Family history of hypertension prevailed more among females as compared to males and those who had hypertension running in family had higher B.P. measure- 
Table 1: Selected Characteristics of Sample Population $(n=400)$ to check frequency of High Blood Pressure.

\begin{tabular}{ccccccccc}
\hline $\begin{array}{c}\text { Diet Con- } \\
\text { scious }\end{array}$ & $\begin{array}{c}\text { Red Meat } \\
\text { Users }\end{array}$ & $\begin{array}{c}\text { White Meat } \\
\text { Users }\end{array}$ & $\begin{array}{c}\mathbf{1 8 . 5 - 2 4 . 5} \\
\mathbf{1 8}\end{array}$ & $\begin{array}{c}\text { Less than } \\
\mathbf{1 8 . 5}\end{array}$ & $\begin{array}{c}\text { BMI Greater than } \\
\mathbf{2 4 . 5}\end{array}$ & $\begin{array}{c}\text { Family History } \\
\text { of Hypertension }\end{array}$ & $\begin{array}{c}\text { Socio-Economic } \\
\text { Stress }\end{array}$ & $\begin{array}{c}\text { Personality Fac- } \\
\text { tors }\end{array}$ \\
\hline $71.75 \%$ & 134 & 253 & 264 & 39 & 97 & 81 & 68 & 35 \\
\hline
\end{tabular}

Table 2: Prevalence of High B.P. (Hypertension) amongst Red Meat Users.

\begin{tabular}{|c|c|c|c|c|}
\hline B.P. in Red Meat Users & $\begin{array}{c}\text { Males } \\
n=71\end{array}$ & $\begin{array}{c}\text { Males } \\
n=38\end{array}$ & $\begin{array}{c}\text { Female } \\
\mathbf{n}=14\end{array}$ & $\begin{array}{c}\text { Females } \\
n=11\end{array}$ \\
\hline No of Individuals & 71 & 38 & 14 & 11 \\
\hline Systolic B.P. $\pm 5 \mathrm{~mm} \mathrm{Hg}$ & 129 & 148 & 125 & 141 \\
\hline Diastolic B.P. $\pm 5 \mathrm{~mm} \mathrm{Hg}$ & 69 & 84 & 73 & 85 \\
\hline
\end{tabular}

Table 3: Prevalence of High B.P. (Hypertension) amongst Underweight, Normal and Obese Individuals Using BMI Parameter.

B.P. in Individuals having Males having Females having Males having Females having Males having Females having

BMI $<18.5$

Systolic B.P. $\pm 5 \mathrm{~mm} \mathrm{Hg} \quad 125 \quad 137$

Diastolic B.P. $\pm 5 \mathrm{~mm} \mathrm{Hg}$

$64 \quad 79$

$\begin{array}{ccc}\mathbf{8} .5 & \text { BMI } & <\mathbf{1 8 . 5} \\ 3 & 11 & 9 \\ 137 & 131 & 145 \\ 79 & 71 & 81\end{array}$

\begin{tabular}{|c|c|c|c|c|c|c|c|}
\hline \multicolumn{2}{|c|}{$\mathrm{BMI}>24.5$} & \multicolumn{2}{|c|}{ BMI $>24.5$} & \multicolumn{2}{|c|}{ BMI 18.5-24.5 } & \multicolumn{2}{|c|}{ BMI 18.5-24.5 } \\
\hline 20 & 17 & 47 & 13 & 76 & 30 & 98 & 60 \\
\hline 125 & 147 & 127 & 146 & 122 & 142 & 129 & 143 \\
\hline 80 & 89 & 75 & 86 & 73 & 84 & 74 & 85 \\
\hline
\end{tabular}

Table 4: Prevalence of High B.P. (Hypertension) amongst Individuals having Family history of Hypertension.

\begin{tabular}{ccccc}
\hline $\begin{array}{c}\text { Family history of Hyper- } \\
\text { tension }\end{array}$ & $\begin{array}{c}\text { Males having Family } \\
\text { history of Hypertension }\end{array}$ & $\begin{array}{c}\text { Females having Family } \\
\text { history of Hypertension }\end{array}$ & $\begin{array}{c}\text { Males not having Family } \\
\text { history of Hypertension }\end{array}$ & $\begin{array}{c}\text { Females not having Family } \\
\text { history of Hypertension }\end{array}$ \\
\hline $\begin{array}{c}\text { No of Individuals } \\
\text { Systolic B.P. } \pm 5 \mathrm{~mm} \mathrm{Hg}\end{array}$ & 54 & 79 & 108 & 159 \\
Diastolic B.P. $\pm 5 \mathrm{~mm} \mathrm{Hg}$ & 84 & 145 & 124 & 142 \\
\end{tabular}

Table 5: Prevalence of High B.P. (Hypertension) amongst Individuals having/ not having satisfaction with Current Socioeconomic Status.

\begin{tabular}{|c|c|c|c|c|}
\hline Socioeconomic Status & $\begin{array}{l}\text { Males satisfied with current } \\
\text { Socioeconomic status }\end{array}$ & $\begin{array}{l}\text { Females satisfied with cur- } \\
\text { rent Socioeconomic status }\end{array}$ & $\begin{array}{l}\text { Males not satisfied with cur- } \\
\text { rent Socioeconomic status }\end{array}$ & $\begin{array}{c}\text { Females not satisfied with } \\
\text { current Socioeconomic status }\end{array}$ \\
\hline No of Individuals & 69 & 75 & 93 & 163 \\
\hline Systolic B.P. $\pm 5 \mathrm{~mm} \mathrm{Hg}$ & 132 & 138 & 139 & 142 \\
\hline Diastolic B.P. $\pm 5 \mathrm{~mm} \mathrm{Hg}$ & 80 & 76 & 81 & 83 \\
\hline
\end{tabular}

Table 6: Prevalence of High B.P. (Hypertension) amongst Smokers.

\begin{tabular}{ccc}
\hline Information & Males & Females \\
\hline No of Individuals & 33 & 05 \\
Systolic B.P. $\pm 5 \mathrm{~mm} \mathrm{Hg}$ & 143 & 147 \\
Diastolic B.P. $\pm 5 \mathrm{~mm} \mathrm{Hg}$ & 87 & 77 \\
\hline
\end{tabular}


ments in comparison to those who had no such history. Males and females not satisfied with their socioeconomic status had higher B.P. as compared to those who were satisfied with their socioeconomic status. Smokers also had higher than normal B.P. values. Among those who had red meat as routine part of their diet, most had normal B.P. but $36 \%$ of them had B.P. greater than normal. According to a report, one billion people in the world are suffering from hypertension. Hypertension is a major risk factor for myocardial infarction, stroke, heart failure, renal failure and retinopathy. It leads to fatal outcome and needs to be prevented.

\section{CONCLUSION}

Being overweight and stressful is strongly associated with hypertension among business class community. While hypertension is a serious predisposing factor to cardiac and vascular diseases, its prevention, diagnosis, management and treatment should be strongly recommended in all the youngsters to avoid future complications which may prove to be fatal. We suggest that awareness of importance of blood pressure for maintaining a good health; and adaptation of a healthy lifestyle to hinder the development of hypertension among suspected individuals should be stressed upon.

\section{CORRESPONDING AUTHOR PROFILE}

Muhammad Asim Farooq is a final professional Pharm.D student in Lahore College of Pharmaceutical Sciences, Lahore, Pakistan. He has a keen interest in research topics related to community health issues and is actively involved in various Public Health Awareness Campaigns being conducted through the platform of different NGOs.

\section{REFERENCES}

Gupta, A., Brahmbhatt, K., Prasanna, K., Halappanavar, A.B., (2016). Prevalence and correlates of hypertension in the rural community of

dakshina kannada, karnataka, india. International Journal of Medical Science and Public Health, 5(2)

Ibrahim, M.M., Damasceno, A., (2012). Hypertension in developing countries. The Lancet, 380(9841), 611-619. [DOI]

Ke, L, Ho, J., Feng, J., Mpofu, E, Dibley, M.J, Li, Y, Feng, X, Van, F, Lau, W., Brock, K.E., (2015). Prevalence, awareness, treatment and control of hypertension in macau: Results from a cross-sectional epidemiological study in Macau, China. American journal of hypertension, 28(2), 159165. [DOI]

Keshari, P., Shankar, H., (2015). Behavioural risk factors and hypertension among 40 years and above age group in urban Varanasi. The Journal of Community Health Management, 2(1), 17-21.

Ogah, O.S., Rayner, B.L., (2013). Recent advances in hypertension in subSaharan Africa. Heart, heartjnl-2012-303227. [DOI]

Premkumar, R., Pothen, J., Rima, J., Arole, S., (2016). Prevalence of hypertension and prehypertension in a community-based primary health care program villages at central India. Indian Heart Journal. [DOI] 